DOI: https://doi.org/10.24144/2409-6857.2020.1(55).36-40

УДК 330.522.4(477)

Мельник В.І., Погріщук Б.В.

\title{
ОРГАНІЗАЦІЙНО-ЕКОНОМІЧНІ ЗАСАДИ ПЕРСПЕКТИВНОГО РОЗВИТКУ ДЕРЖАВНОГО РЕЗЕРВУ УКРАЇНИ
}

\begin{abstract}
У статті розкрито змістовий контент державний резерву як одного з найбільш важливих елементів економічної безпеки країни. Визначено завдання стратегічного запасу щьодо формування оптимальної структури матеріальних цінностей, системи організації обслуговування, зберігання та використання запасів державного резерву відповідно до потреб держави. Обгрунтовано наукові підходи до формування стратегічних запасів держави з урахуванням міжнародного досвіду. Визначено наявні проблеми державного резерву та обтрунтовано напрями формування ефективної моделі перспективного розвитку державного резерву Украӥни
\end{abstract}

Ключові слова: державний резерв, економічна безпека, національна безпека, стратегічні запаси, матеріально-технічні иінності.

Постановка проблеми. Інститут формування державного резерву широко використовується для забезпечення безперебійного функціонування і стабілізації економіки у випадку надзвичайних обставин, наявних ризиків, ресурсних обмежень та інших загроз національній безпеці, що можуть призвести до суттєвих порушень у системі виробничо-господарських зв'язків. Роль держави i ступінь іiі втручання в економічне життя доцільно розглядати за показниками результативності іiі діяльності у задоволенні потреб населення. Інститути державної влади знаходяться в центрі економічного і соціального розвитку країни, але не в якості безпосереднього джерела зростання, а як партнера, каталізатора i помічника [1, с.48].

Існуючий стан розвитку промисловості України перебуває у вкрай небезпечній, тобто критичній, зоні - на межі або нижче нижнього порогового значення, що обумовлено незадовільним рівнем безпеки всіх трьох складових сталого розвитку [2, с.203]. Вектори інтегральних порогових значень складових сталого розвитку (економічна, екологічна, соціальна складові) суттєво відрізняються, що вказує на різну наближеність інтегральних

ФМельник В.I, д.е.н., проф., професор кафедри економіки, обліку та оподаткування Вінницького навчально-наукового інституту економіки Тернопільського національного економічного університету, тел.0679942127; E-mail: melnyk.vc@gmail.com

Погріщук Б.В. д.е.н., проф., професор кафедри економіки, обліку та оподаткування Вінницького навчально-наукового інституту економіки Тернопільського національного економічного університету, тел.0432554955; E-mail: gpogrischuk@gmail.com 36 індексів до середнього оптимального значення для кожної складової сталого розвитку економіки.

У зв'язку з цим динаміка відхилень поточних значень інтегральних індексів від їх середніх оптимальних значень визначатиме стан сталого розвитку та важливість загроз його складових, що посилює актуальність дослідження перспективного розвитку державного резерву в сучасних умовах функціонування національного господарства.

Аналіз останніх досліджень і публікацій. Питанню формування державного резерву, його ролі та місця в системі економічної безпеки присвятили праці: О. Вдовін, Г. Вознюк, Т. Гордієнко, А. Загородній, С. Коваленко, М. Потетюєва, О. Скорук, В. Третяк, Ю. Харазішвілі, П. Щипанський та інші. Проте проблема розвитку державного резерву залишається недостатньо дослідженою, зважаючи на сучасні зміни в побудові економічних зв'язків та потребі врахування державної підтримки в умовах складної економічної та соціально-політичної ситуації в країні та у світі.

Метою статті $є$ обгрунтування організаційноекономічних засад перспективного розвитку державного резерву України. Завдання дослідження передбачають: розкриття змістового контенту державного резерву як одного 3 найбільш важливих елементів економічної безпеки країни; визначення завдань стратегічного запасу щодо формування оптимальної структури матеріальних цінностей, системи організації обслуговування, зберігання та використання запасів державного резерву; обгрунтування напрямів формування ефективної моделі перспективного розвитку державного резерву України.

Виклад основного матеріалу. Подальший розвиток ринкових відносин неможливий без 
вивчення теоретико-методичних аспектів проблеми створення ефективного механізму забезпечення економічної безпеки, тому актуальним $є$ розуміння сутності економічної безпеки та визначення іiі складових елементів, а також своєчасного виявлення впливу негативних загроз-факторів із метою створення власної системи економічної безпеки, що надасть можливість уникнути руйнівних наслідків становлення національної економіки та забезпечити їі конкурентоспроможність [3, с.41].

Державний резерв $є$ одним 3 найбільш важливих елементів економічної безпеки поряд 3 такими їі складовими як мобілізаційна підготовка економіки держави, іiі території та комунікацій та стратегічних ресурсів; наявність чіткої системи стандартизації; наявність твердої національної валюти; імпортна незалежність; бюджетна безпека та наявність висококваліфікованих управлінських кадрів на державному рівні [4, с.8].

Як надійний акумулятор матеріальних цінностей державний резерв може використовуватися для реалізації стимулюючого впливу на ринок та зростання валового національного продукту.

Відповідно до Закону України «Про державний матеріальний резерв», Державний резерв $\epsilon$ особливим державним запасом матеріальних цінностей, призначених для використання в цілях і в порядку, передбачених цим Законом [5].

Державний резерв розглядається як особливий державний запас матеріальних цінностей, призначених для використання 3 метою i в порядку. У складі державного резерву створюється не знижувальний запас матеріальних цінностей [6, с. 769].

Державний резерв являє собою стратегічний запас найважливіших видів промислових та продовольчих товарів, матеріалів сировинних запасів, палива, машин та обладнання та є важливим компонентом системи забезпечення національної безпеки, а також одним 3 найважливіших інструментів держави по оперативному реагуванню на несприятливі та різкі зміни економічної та соціально-політичної ситуації в країні та у світі; виникнення нових загроз, в тому числі терористичних; природних та техногенних катастроф.

Державний резерв України необхідний для [7, c.255]: забезпечення потреб України в особливий період; надання державної підтримки окремим галузям народного господарства та підприємствам 3 метою стабілізації економіки у разі тимчасових порушень термінів постачання важливих видів сировини і паливно-енергетичних ресурсів, продовольства, виникнення диспропорцій між попитом і пропозицією на внутрішньому ринку; надання гуманітарної допомоги; забезпечення першочергових робіт під час ліквідації наслідків надзвичайних ситуацій.

Структурними складовими державного резерву $\epsilon$ :

- мобілізаційний резерв, що утворюється за рахунок запасів матеріально-технічних i сировинних ресурсів, призначених для забезпечення розгортання виробництва військової та іншої промислової продукції, ремонту техніки та майна в особливий період, воєнний час, під час робіт із відновлення залізничних та автомобільних доріг, морських i річкових портів, аеродромів, ліній i споруд зв'язку, газо-, нафтопродуктопроводів, систем енерго- i водопостачання для організації безперебійної роботи промисловості, транспорту і зв'язку, надання медичної допомоги;

- запаси сировинних, матеріально-технічних i продовольчих ресурсів, призначені для забезпечення стратегічних потреб країни;

- запаси матеріально-технічних ресурсів для виконання першочергових робіт під час ліквідації наслідків надзвичайних ситуацій та для виконання інших заходів, передбачених чинним законодавством[8, с.69].

У міжнародному просторі набули поширення такі підходи до формування стратегічних запасів, як: акумулювання безпосередньо у державних резерв та формування комерційних резервів шляхом введення державних зобов'язань на приватні компанії щодо резервування. Державні резерви можуть використовуватися 3 метою підтримки низькорентабельного виробництва у стратегічних галузях, захисту населення в умовах зростання цін на товари. Привабливість комерційних резервів пояснюється тим, що вони не потребують бюджетних витрат. Проте лише державне резервування уможливлює оперативне реагування у надзвичайних ситуаціях, забезпечує реалізацію управлінського підходу до стану державних запасів, а також дозволяє залучати значні обсяги матеріальних цінностей.

Ефективне функціонування системи державного резерву забезпечують підприємства, установи i організації, на яких зберігаються матеріальні цінності держрезерву. Нині втрачено значну кількість інфраструктурних об'єктів системи державного резерву i запасів матеріальних цінностей, що були першочергово створені. Державний матеріальний резерв, як стратегічний запас держави, використання якого чітко регламентується законодавством, дедалі більше використовується для вирішення 
поточних проблем. Внаслідок інтенсивного використання протягом останніх років ресурсів державного матеріального резерву, хронічного неповернення запозиченого в установлені строки, проведення розрахунків 3 Держкомрезервом за відпущені матеріальні ресурси шляхом здійснення взаємозаліків, значно зменшено наявні обсяги багатьох видів продукції [9].

Для вирішення багатьох проблемних аспектів формування державного резерву Міністерством економічного розвитку і торгівлі розроблено новий підхід до реорганізації структури державного резерву, що стосується переходу від централізованої системи формування державного резерву до сучасної ефективної системи стратегічних запасів, побудованої на європейських цінностях, що включатиме як змішану та децентралізовану модель функціонування та враховує сучасні трансформації у сфері соціально-економічного розвитку держави. Так, 3 метою підвищення ефективності управління підприємствами системи державного резерву та економії бюджетних коштів Держкомрезервом проводяться заходи 3 оптимізації мережі підприємств, що входять до сфери його управління: об'єднані державні підприємства та організації системи державного резерву, що дозволило сконцентрувати матеріальні i фінансові ресурси, підвищити ефективність управлінських рішень і вирішити соціальні питання працівників таких підприємств без скорочення їх штатної чисельності [10]

Проте глобалізаційні зміни, посилення конкуренції на міжнародних ринках, необхідність гарантування економічної безпеки держави при одночасному розвитку інтеграційних зв'язків здійснили вплив на формування принципів, еталонів функціонування, фінансування, управління використання та розподілу матеріальних цінностей.

Процедури розподілу накопичених у системі державного резерву матеріальних цінностей мають бути обов'язковою складовою національної системи пріоритетів, що є гарантією оптимального їх використання для організації протидії наявним загрозам у всіх сферах життєдіяльності держави. Зазначені резерви можуть знаходитись на утриманні уряду, державних або приватних компаній, які виробляють відповідну продукцію. Накопичення i зберігання приватними компаніями резервів здійснюється відповідно до закону або укладених контрактів, а компанії зобов'язані періодично оновлювати матеріали, що зберігають [11].
Суттєвими проблемами на шляху ефективного розвитку державного резерву визначено:

- виконання державним резервом функції поточного джерела забезпечення матеріальнотехнічними ресурсами, сировиною $\mathrm{i}$ продовольчими товарами окремих споживачів;

- наявні неузгодженості у сфері організації аутсорингу та управлінських процесів, що зумовлені діяльністю підконтрольних суб' єктів, а саме щодо закупівель, оновлення та розподілу матеріальних цінностей державного резерву;

- розпорошеність матеріальних цінностей й потужностей державних підприємств i організацій державного резерву по значній кількості зберігачів, що відносяться до сфери управління Держкомрезерву, які використовувалися лише в незначних обсягах.

- недостатня забезпеченість надійності системи зберігання матеріальних цінностей державного резерву та використання потужностей зберігачів ресурсів державного резерву;

- використання цінностей державного резерву не за цільовим призначенням;

- незадовільне проведення оновлення матеріальних резервів, зберігання фізично або морально застарілих цінностей;

- необхідність залучення додаткових фінансових ресурсів для покриття різниці між ціною реалізації матеріальних цінностей, що у результаті довготривалого зберігання втратили вартісні та якісні характеристики.

Нівелювання наявних проблем державного резерву України може мати наслідком несвоєчасну та неповну допомогу у разі виникнення загроз економічній та національній безпеці держави.

Встановлення та вирішення стратегічних завдань розвитку державного резерву дозволить приймати ефективні рішення, зосереджувати ресурси держави на вирішення першочергових питань та впроваджувати міжнародний досвід.

3 метою формування ефективної моделі перспективного розвитку державного резерву необхідно забезпечити вирішення таких завдань, як:

- розширення функцій Держкомрезервом у сфері надійної системи зберігання матеріальних цінностей, підвищення ефективності використання наявних потужностей, їх оновлення державними зберігачами;

- формування та реалізації державної політики у сфері формування, розміщення, зберігання, використання, поповнення та поновлення запасів державного резерву; 
- удосконалення моделі управління державним резервом на основі оптимізації піi внутрішньої структури;

- забезпечення високого рівня підготовки кадрів, які залучені до системі формування та діяльності державного резерву;

- посилення контролю у сфері управління та діяльності Держкомрезерву через розробку та удосконалення механізмів закупівлі та реалізації різних матеріальних цінностей для державного резерву;

- удосконалення механізму залучення ресурсів та матеріальних цінностей, встановлення їх граничних обсягів за обгрунтувати напрями їх територіального розміщення та використання;

- оптимізації систем зберігання на основі впровадження сучасних наукових досягнень, інноваційних ресурсозберігаючих технологій;

- посилення відповідальності за ціноутворення, контроль за технічним станом будівель і споруд, підрозділи мобілізаційного резерву та ін.

Висновки та перспективи подальших досліджень. Державний резерв є визначальним чинником економічної безпеки країни, відтак при формуванні перспективних напрямів його розвитку необхідно враховувати: стратегічні засади національної безпеки, ймовірність виникнення та потенційний масштаб природних катаклізмів i техногенних ситуацій, економічний та фінансовий стан держави, наукові досягнення та соціально-економічний, виробничий потенціал країни, а також можливості впровадження інновацій у систему державного матеріального резерву.

До основних проблем на шляху ефективного розвитку державного резерву віднесено: використання державного резерву як поточного джерела забезпечення ресурсами; неузгодженості у сфері організації аутсорингу та управлінських процесів; недостатня забезпеченість надійності системи зберігання матеріальних цінностей; розпорошеність матеріальних цінностей та потреба оновлення потужностей для зберігання ресурсів державного резерву та використання потужностей зберігачів ресурсів державного резерву; необхідність залучення додаткових фінансових ресурсів для покриття різниці між ціною реалізації матеріальних цінностей, що у результаті довготривалого зберігання втратили вартісні та якісні характеристики.

3 метою формування ефективної моделі перспективного розвитку державного резерву необхідно забезпечити вирішення таких завдань, як: розширення функцій Держкомрезерву щодо підвищення ефективності використання наявних потужностей та їх оновлення; удосконалення моделі управління державним резервом на основі оптимізації іï внутрішньої структури; забезпечення високого рівня підготовки кадрів, які залучені до системи формування та діяльності державного резерву; оптимізації систем зберігання шляхом впровадження сучасних наукових досягнень, інноваційних ресурсозберігаючих технологій; посилення контролю та відповідальності в процесі формування та використання державного резерву.

\section{ПЕРЕЛІК ВИКОРИСТАНИХ ДЖЕРЕЛ}

1. Погріщук Б.В. Економічна безпека аграрного сектору у системі економічної безпеки держави. Науковий вісник Ужгородського Університету. Серія Економіка. 2019. Випуск 1 (53). С.48-52.

2. Харазішвілі Ю.М. Системна безпека сталого розвитку: інструментарій оцінки, резерви та стратегічні сценарії реалізації: монографія. НАН України, Інститут економіки та промисловості. Київ, 2019. 304 с.

3. Скорук О. Економічна безпека держави: сутність, складові елементи та проблеми забезпечення. Науковий вісник Ужгородського національного університету. Серія «Міжнародні економічні відносини та світове господарство». 2016. Вип. 6(3). С. 39-42.

4. Третяк В. В., Гордієнко Т. М. Економічна безпека: сутність та умови формування. Економіка та держава, 2010. №1. C.6-8.

5. Про державний матеріальний резерв: Закон України від 24.01.1997p. №51/97. BP. URL: http://zakon3.rada.gov.ua/laws/show/51/97

6. Загородній А. Г. Вознюк Г. Л. Фінансово-економічний словник. К.: Знання, 2007. 1072 с.

7. Коваленко С. О. Державний резерв як головний компонент системи забезпечення національної безпеки України. Зовнішня торгівля: право, економіка, фінанси, 2012. № 3. C.253-260. URL: http://zt.knute.edu.ua/files/2012/03(62)2012/3_12_37.pdf

8. Потетюєва М. Мобілізаційний резерв як складова системи забезпечення безпеки держави. Соціальний розвиток та безпека. 2018. №. 5. С.66-75.

9. Коваленко С.О. Державний матеріальний резерв України: проблеми та перспективи функціонування. Вісник ХНАУ ім. В.В. Докучаєва. Серія «Економічні науки», 2015. № 1. С. 100-108. URL: https://knau.kharkov.ua/ uploads/visn_econom/2016/1/13.pdf. 
10. Концепція реформування системи Державного резерву України. Проект. MEPT. Київ. 2015. URL: https://issuu.com/mineconomdev/docs/ conception_short_v2_sept2015_1_.

11. Щипанський П. В. Вдовін О. Г. Мобілізаційний резерв як фактор збільшення можливостей національної економіки задовольнити потреби Збройних Сил України. Збірник наукових праць Центру воєнно-стратегічних досліджень Національного університету оборони України імені Івана Черняховського, 2019. № 2(66). С. 22-28.

\section{REFERENCES}

1. Pohrishchuk, B.V. (2019). Ekonomichna bezpeka ahrarnoho sektoru u systemi ekonomichnoi bezpeky derzhavy [Economic security of the agricultural sector in the system of economic security of the state]. Naukovyi visnyk Uzhhorodskoho Universytetu Seriia Ekonomika - Scientific Bulletin of Uzhhorod University, 1 (53), 48-52 [in Ukrainian].

2. Kharazishvili, Yu.M (2019). Systemna bezpeka staloho rozvytku: instrumentarii otsinky, rezervy ta stratehichni stsenarii realizatsii [System security of sustainable development: assessment tools, reserves and strategic implementation scenarios]. Kyiv: NAN Ukrainy, Insytut ekonomiky ta promyslovosti [in Ukrainian].

3. Skoruk, O. (2016). Ekonomichna bezpeka derzhavy: sutnist, skladovi elementy ta problemy zabezpechennia [Economic security of the state: essence, constituent elements and problems of providing]. Naukovyi visnyk Uzhhorodskoho natsionalnoho universytetu - Scientific Bulletin of Uzhhorod University, 6(3), 39-42 [in Ukrainian].

4. Tretiak, V.V., \& Hordiienko, T.M. (2010). Ekonomichna bezpeka: sutnist ta umovy formuvannia [Economic security: the essence and conditions of formation]. Ekonomika ta derzhava - Economy and state, 1, 6-8 [in Ukrainian].

5. Zakon Ukrainy Pro derzhavnyi materialnyi rezerv : pryiniatyi 24 sich. 1997 roku № 51/97-VR [Law of Ukraine on the state material reserve activity from January 24 1997, № 51/97]. (1997, January 24). Retrieved from http://zakon3.rada.gov.ua/laws/show/51/97 [in Ukrainian].

6. Zagorodniy, A.G., \& Voznyuk, G.L. (2007). Financial and economic dictionary [Financial and economic dictionary]. Kyiv: Znannia [in Ukrainian].

7. Kovalenko, S.O. (2012). Derzhavnyi rezerv yak holovnyi komponent systemy zabezpechennia natsionalnoi bezpeky Ukrainy [State reserve as the main component of the national security system of Ukraine]. Zovnishnia torhivlia: pravo, ekonomika, finansy - Foreign trade: law, economics, finance, 3, 253-260. Retrieved from http://zt.knute.edu.ua/files/2012/03(62)2012/3_12_37.pdf [in Ukrainian].

8. Potetiuieva, M. (2018). Mobilizatsiinyi rezerv yak skladova systemy zabezpechennia bezpeky derzhavy [Mobilization reserve as a component of the state security system]. Sotsialnyi rozvytok ta bezpeka - Social development \& security, 5, 66-75 [in Ukrainian].

9. Kovalenko, S.O. (2015). Derzhavnyi materialnyi rezerv Ukrainy: problem ta perspektyvy fynktsionyvannia [State material reserve of Ukraine: problems and prospects of functioning]. Visnyk KhNUU them. V.V. Dokuchaeva - Bulletin of KhNAU named after V.V. Dokuchaeva, 1, 100-108. Retrieved from https://knau.kharkov.ua/ uploads/visn_econom/2016/1/13.pdf [in Ukrainian].

10. Kontseptsiya reformuvannia systemy Derzhavnogo rezervu Ukrainy: Proekt [Concept of reforming the system of the State Reserve of Ukraine: Project]. (2015). Kyiv: Ministry of Economic development and Trade. Retrieved from https://issuu.com/mineconomdev/docs/conception_short_v2_sept2015_1_[in Ukrainian].

11.Shchypanskyi, P.V., \& Vdovin, O.H. (2019). Mobilizatsiinyi rezerv yak faktor zbilshennia mozhlyvostei natsionalnoi ekonomiky zadovolnyty potreby Zbroinykh Syl Ukrainy. Zbirnyk naukovykh prats tsentru voiennostratehichnykh doslidzhen Natsionalnoho universytetu oborony Ukrainy imeni Ivana Cherniakhovskoho - Collection of scientific works of the Center for Military Strategic Studies of the Ivan Chernyakhovsky National University of Defense of Ucraine, 2(66), 22-28 [in Ukrainian].

Отримано 29.08.2020 